\title{
Antimicrobial Effect of Lactic Acid Bacteria against Common Pathogenic Bacteria
}

\author{
Mohammad Mohammaddoost Chakoosari \\ (Msc) \\ Young Researchers and Elites Club, Lahijan \\ Branch, Islamic Azad University, Lahijan, Iran \\ Mohammad Faezi Ghasemi (PhD) \\ Assistant Professor of Microbiology, \\ Department of Microbiology, Islamic Azad \\ University of Lahijan, Guilan, Iran \\ Alireza Masiha (MSc) \\ Department of Biotechnology, Faculty of Basic \\ Sciences, Lahijan Branch, Islamic Azad \\ University, Lahijan, Iran \\ Reza Kazemi Darsanaki (MSc) \\ Young Researchers and Elites Club, Lahijan \\ Branch, Islamic Azad University, Lahijan, Iran

\section{Abolfazl Amini (Msc)} \\ Laboratory Sciences Research Center, Golestan \\ University of Medical Sciences, Gorgan, Iran \\ Corresponding Author: Mohammad \\ Mohammaddoost Chakoosari \\ Email: Chakoosari@hotmail.com \\ Tel: +989113335181
}

Address: Islamic Azad University of Lahijan, Guilan, Iran

Received : 19 Mar 2013

Revised: 10 Aug 2014

Accepted: 14 Agu 2014

\begin{abstract}
Background and Objective: Probiotics are living microorganisms that have beneficial effects on the health of digestive system. The aim of this study was to evaluate the antimicrobial ability of acidic and neutral supernatants (culture supernatant) of lactic acid bacteria against common bacterial pathogens.

Methods: Four species of lactic acid bacteria (Lactobacillus plantarum PTCC1745, Lactobacillus PTCC1608, Lactobacillus Saki PTCC1712 and Lactobacillus Lactis PTCC1336) were obtained from the microbial collection of Iranian Research Organization for Science and Technology in Lyophilized form. The antimicrobial activity of neutral and acidic supernatants against bacterial pathogens was investigated using the Disk and Well Diffusion Agar methods.

Results: Lactic acid bacteria showed good antimicrobial ability against six pathogenic bacteria with the highest inhibitory effect observed in Lactococcus lactis against E. coli PTCC1399 through well method with an average diameter of $14 \mathrm{~mm}$ inhibition zone. In this study, the well diffusion method was far more sensitive compared to the disk method and acidic supernatants showed higher antimicrobial efficiency compared to neutral types.

Conclusion: the Metabolites produced by lactic acid bacteria are able to inhibit the growth of pathogenic bacteria that can be an important and practical solution for the prevention and treatment of infections and ultimately improve human health.
\end{abstract}

Keywords: Lactobacillus; Lactococcus; Probiotic; Antibacterial. 


\section{INTRODUCTION}

Lactic acid bacteria such as Lactobacillus, Lactococcus and Bifidobacterium are food supplements with beneficial effects on the host that can help balance the intestinal flora (1). The mechanism of these bacteria on promotion of health can be attributed to settling in the intestine and proliferation, regulation and control of intestinal microflora, reinforcement of intestinal mucosal wall, affecting the permeability of the intestinal mucosa, prevention of pathogenic bacteria adhesion to the intestinal mucosa, prevention and treatment of gastrointestinal disorders, antibiotic activity against pathogens, regulation of bacterial enzyme activity, preventing the side effects of antibiotic treatment, the change in protein diet, basic digestion of proteins, vitamin synthesis, improved calcium absorption, lactose metabolism, reduced lactose intolerance, improved digestion abilities, enhancing the nutritional value of products, preventing allergies, reduced blood cholesterol, improved immunity, anti-cancer effec ts and non-beneficial bacteria growth inhibition (25). Lactic acid bacteria by producing lactic and acetic acid, bacteriocin, hydrogen peroxide, diacetyl, acetaldehyde and ammonia are capable of reducing the environmental $\mathrm{pH}$ and inhibit the growth of many microorganisms (6). Nowadays, with the increased antibiotic resistance and side effects caused by using chemical drugs, the use of alternative therapies seems necessary. The previous studies have well established that these bacteria and their produced metabolites can have wide therapeutic applications as well as a positive role in pathogen inhibition (7). The aim of this study was to evaluate the anti-microbial ability of neutralized and acidic culture supernatant fluid of lactic acid bacteria on common bacterial pathogens.

\section{MATERIAL AND METHODS}

In this study, four standard strains (Lactobacillus plantarum subspecies plantarum PTCC1745, Lactobacillus casei subspecies casei PTCC1608, Lactobacillus Saki subspecies Saki PTCC1712 and Lactobacillus lactis subspecies lactis PTCC1336) were obtained from the microbial collection of Iranian Research Organization for Science and Technology (IROST). All four strains were then cultured on liquid MRS medium and incubated for $24 \mathrm{~h}$ at $37^{\circ} \mathrm{C}$ anaerobically.Purified lactic acid bacteria in liquid MRS medium and at $37^{\circ} \mathrm{C}$ were incubated for $24 \mathrm{~h}$ in anaerobic conditions until turbidity equal to 0.5 McFarland (1.5x108 cfu/ml) was achieved. In order neutralize the culture supernatant. Four common pathogenic bacteria strains, including Staphylococcus aureus PTCC 1431, Escherichia coli PTCC 1399, Shigella dysentery PTCC 1188 and Salmonella enterica PTCC 1231 were obtained from the microbial collection of IROST. Escherichia coli and Staphylococcus aureus were obtained from a medical laboratory in nutrient broth medium with turbidity equivalent to $0.5 \mathrm{McFarland}$. Mueller Hinton agar was used to evaluate the antimicrobial activity of lactic acid bacteria by implementing the disk (Disk Diffusion Agar) and wells (Well Diffusion Agar) methods to measure the inhibitory effect. The antagonism effect of acidic and neutralized supernatants of these bacteria was evaluated on six standard and clinical pathogenic strains and repeated three times to reduce error.

Wells method (Well Diffusion Agar):

In this method, culture was done on Mueller Hinton agar medium with a sterile swab from a suspension of pathogenic bacteria in nutrient broth medium (0.5 McFarland). Wells were created using a sterile Pasteur pipette on the medium and $0.1 \mathrm{ml}$ of both supernatants (acidic and neutralized with $\mathrm{NaOH}$ ) of lactic acid bacteria were added to the wells. After medium dried out, the plates were incubated for 24 $h$ at $37^{\circ} \mathrm{C}$. Then diameter of growth inhibition by lactic acid bacteria against each pathogenic bacterium was measured by a millimeter ruler.

Disk method (Disk Diffusion Agar):

Sterile paper disks with diameter of $6 \mathrm{~mm}$ was treated in the supernatants (acidic and neutralized with $\mathrm{NaOH}$ ) of lactic acid bacteria for $5 \mathrm{~min}$ and the disks were placed to dry out at $37^{\circ} \mathrm{C}$ for $4 \mathrm{~h}$. In this method, from suspension of pathogenic bacteria cultured in nutrient broth ( 0.5 McFarland), culture on Mueller Hinton agar was done using an sterile swab, and then the impregnated disks were placed on the surface of Mueller-Hinton agar with a certain distance from each other and the edge of the plate. The plates were then incubated for $24 \mathrm{~h}$ at $37^{\circ} \mathrm{C}$. Then diameter of growth inhibition by lactic acid bacteria against each pathogenic bacterium was measured by a millimeter ruler. Statistical analysis was performed using SPSS software and each test was repeated three times to reduce error.

\section{RESULTS}

Well diffusion agar: During this procedure, the Lactococcus lactis subspecies lactis had the highest inhibitory effect against E. coli PTCC 1399 with acidic supernatant with an average diameter of 14 $\mathrm{mm}$ inhibition zone. Lactobacillus Saki subspecies 
Saki PTCC 1712 and Lactobacillus plantarum subspecies plantarum PTCC 1745 with neutralized supernatant had the least inhibitory effects, respectively, against Shigella dysentery PTCC 1188 and clinical Staphylococcus aureus, Staphylococcus aureus PTCC 1431 with an average diameter of $8.33 \mathrm{~mm}$ inhibition zone. Other bacteria also showed a high inhibitory ability against pathogenic bacteria with $8.66-13.66 \mathrm{~mm}$ inhibition zone. It has to be noted that acidic supernatant showed higher inhibitory ability compared to neutralized supernatant (Tables 1 and 2). Disk diffusion agar: In this method, Lactobacillus plantarum PTCC1745 showed the highest inhibitory effect against Salmonella centrifuged for $25 \mathrm{~min}$ at $4^{\circ} \mathrm{C}$, and $3500 \mathrm{rpm}$. $1 \mathrm{~N}$ to obtain the culture supernatant, the bacteria were $\mathrm{NaOH}$ was used to

enterica subspecies PTCC 1231 with acidic supernatant with an average diameter of $12.33 \mathrm{~mm}$ inhibition zone. The other bacteria also showed high inhibitory ability with 7.66-11.66 mm inhibition zone against pathogenic bacteria while acidic supernatant had higher inhibitory ability compared to neutralized supernatant (Tables 1 and 2). The comparison of Disk and Well methods showed that Well method had better and higher results while lactic acid bacteria showed more inhibitory effects. Acidic supernatants had higher inhibitory abilities compared to neutralized supernatants.

Table 1- Inhibition amount of lactic acid bacteria against pathogens in millimeters (acidic type)

\begin{tabular}{|c|c|c|c|c|c|c|c|c|c|c|c|c|}
\hline \multirow[b]{2}{*}{ Lactic acid bacteria } & \multicolumn{2}{|c|}{$\begin{array}{c}\text { E.coli } \\
\text { PTCC } 1399\end{array}$} & \multicolumn{2}{|c|}{ Clinical E.Coli } & \multicolumn{2}{|c|}{$\begin{array}{c}\text { Staphylococcus } \\
\text { aureus } \\
\text { PTCC 1431 } \\
\end{array}$} & \multicolumn{2}{|c|}{$\begin{array}{c}\text { Clinical } \\
\text { Staphylococcus } \\
\text { aureus } \\
\end{array}$} & \multicolumn{2}{|c|}{$\begin{array}{c}\text { Salmonella } \\
\text { enterica PTCC } \\
1231 \\
\end{array}$} & \multicolumn{2}{|c|}{$\begin{array}{c}\text { Shigella } \\
\text { dysentery PTCC } \\
1188 \\
\end{array}$} \\
\hline & Well & Disk & Well & Disk & Well & Disk & Well & Disk & Well & Disk & Well & Disk \\
\hline $\begin{array}{l}\text { Lactobacillus Saki } \\
\text { subspecies Saki }\end{array}$ & 12.66 & 11.33 & 12 & 10.33 & 13 & 11.66 & 12.33 & 11 & 12.33 & 11 & 12 & 11 \\
\hline $\begin{array}{l}\text { Lactobacillus casei } \\
\text { subspecies casei }\end{array}$ & 12.33 & 11 & 12 & 11.66 & 12 & 10.33 & 13 & 11 & 12.66 & 11.33 & 12.66 & 10.66 \\
\hline $\begin{array}{l}\text { Lactobacillus plantarum } \\
\text { subspecies plantarum }\end{array}$ & 13.66 & 11.66 & 13.66 & 11 & 13.33 & 11.66 & 13.66 & 10.33 & 12.33 & 12.33 & 12.33 & 10.66 \\
\hline $\begin{array}{l}\text { Lactococcus lactis } \\
\text { subspecies lactis }\end{array}$ & 14 & 10.66 & 13.66 & 11.33 & 13.66 & 11.33 & 13.33 & 11 & 12.66 & 11.66 & 12.33 & 11.33 \\
\hline
\end{tabular}

Table 2- Inhibition amount of lactic acid bacteria against pathogens in millimeters (neutralized type)

\begin{tabular}{|c|c|c|c|c|c|c|c|c|c|c|c|c|}
\hline \multirow[t]{2}{*}{ Bacterial Pathogens } & \multicolumn{2}{|c|}{$\begin{array}{c}\text { E.coli } \\
\text { PTCC } 1399\end{array}$} & \multicolumn{2}{|c|}{$\begin{array}{c}\text { Clinical } \\
\text { E.Coli }\end{array}$} & \multicolumn{2}{|c|}{$\begin{array}{c}\text { Staphylococcus } \\
\text { aureus } \\
\text { PTCC } 1431\end{array}$} & \multicolumn{2}{|c|}{$\begin{array}{c}\text { Clinical } \\
\text { Staphylococcus } \\
\text { aureus }\end{array}$} & \multicolumn{2}{|c|}{$\begin{array}{c}\text { Salmonella enterica } \\
\text { PTCC } 1231\end{array}$} & \multicolumn{2}{|c|}{$\begin{array}{c}\text { Shigella dysentery } \\
\text { PTCC } 1188\end{array}$} \\
\hline & Well & Disk & Well & Disk & Well & Disk & Well & Disk & Well & Disk & Well & Disk \\
\hline $\begin{array}{l}\text { Lactobacillus Saki } \\
\text { subspecies } \text { Saki }\end{array}$ & 9.66 & 7.66 & 8.66 & 8 & 10 & 9 & 9 & 8.33 & 10 & 8.33 & 8.33 & 8 \\
\hline $\begin{array}{l}\text { Lactobacillus casei } \\
\text { subspecies casei }\end{array}$ & 9.33 & 8 & 9 & 7.66 & 8.66 & 7.66 & 8.66 & 8 & 8.66 & 9 & 9 & 7.66 \\
\hline $\begin{array}{l}\text { Lactobacillus plantarum } \\
\text { subspecies plantarum }\end{array}$ & 10.33 & 9.33 & 9 & 7.66 & 8.33 & 8.33 & 8.33 & 9 & 9.33 & 8 & 10 & 9.33 \\
\hline $\begin{array}{l}\text { Lactococcus lactis } \\
\text { subspecies lactis }\end{array}$ & 10.66 & 9.66 & 11 & 8.33 & 11.66 & 8.33 & 9 & 8.66 & 10 & 7.66 & 11.33 & 9 \\
\hline
\end{tabular}

\section{DISCUSSION}

Lactic acid bacteria reduce $\mathrm{pH}$ and inhibit the growth of many bacteria by producing lactic and organic acids. These bacteria due to production of antimicrobial compounds such as bacteriocins can be used as natural preservatives (bacteriocins are ribosomal synthetized proteins which are secreted by bacteria and act as antibiotics) (9). It was demonstrated in this study that the metabolites Produced by lactic acid bacteria, isolated by
Centrifugation in neutralized and acidic forms can prevent the growth of pathogenic bacteria. In Boris study, the Lactobacillus isolated from dairy products inhibited the growth of Pseudomonas aeruginosa, Staphylococcus aureus, Escherichia coli, Salmonella typhimurium and Bacillus subtilis with the highest inhibitory effect on Staphylococcus aureus(10). In Kazemi et al. 
study, antimicrobial activity of three Lactobacillus strains against three strains of pathogens (Staphylococcus aureus, Salmonella typhi and E. coli) were investigated and the Lactobacillus strains showed acceptable inhibition ability against pathogens (Lactobacillus plantarum against Salmonella typhi-10.8mm) (9). Coconnier et al. stated that the use of Lactobacillus fermentum, Lactobacillus casei, Lactobacillus acidophilus and Lactococcus lactis supernatant has inhibitory effects on a wide range of pathogenic bacteria (11). Ogunbanwo et al. investigated the antimicrobial activity and bacteriocin production of two probiotic types on several pathogenic bacteria and found the highest inhibitory effect on Bacillus cereus (12).

Ouwehand et al. reported that the antimicrobial effects on gram-positive probiotic bacteria are more than the Gram-negatives (13). Savadogo et al. studied the invitro antimicrobial activity of lactic acid bacteria against standard strains of Bacillus cereus, Enterococcus faecalis, Escherichia coli and Staphylococcus aureus and reported inhibitory zones of $8-12 \mathrm{~mm}$ diameter (14). Strus et al.

\section{REFERENCES}

1. Hammes WP, Hertel C. Research approaches for pre and probiotics :Challenges and outlook. Food Res Int 2002; 35(23):165-70.

2. Kazemi Darsanaki R, Issazadeh K, Khoshkholgh Pahlaviani MRM, Azizollahi Aliabadi M. Antimutagenic Activity of Lactobacillus spp. Isolated from Fresh Vegetables against Sodium Azide and 2-Nitrofluorene. J Pure Appl Microbio. 2012; 6(4): 1677-1682.

3. Çaglar E, Kargul B, Tanboga I. Bacteriotherapy and probiotics' role on oral health. Oral Diseases. 2005; 11(3): 131-137.

4. Day AS, Keenan JI. Probiotic-mediated modulation of host inflammation. Expert Rev Gastroenterol Hepatol. 2011; 5(3): 319-321.

5. Zerehpoosh S, Kazemi Darsanaki R. Probiotics and Health. Journal of Biology and today's world. 2013; 2(1): 41-52.

6. Bromberg R, Moreno I, Zaganini C, Delboni RR, Oliveira J. Isolation of bacteriocin- production lactic acid bacteria from meat and meat product and its spectrum of inhibitory activity. Brazilian Journal of Microbiology. 2004; 35(1-2): 137-144.

7. Klewicki R, Klewicka E. Antagonistic activity of lactic acid bacteria as probiotics against Selected bacteria of the Enterobacteriacae family in the presence polyols and their galactosyl derivertives. Biotechnology letters. 2004; 26(4): 317-320.

8. Shirazi L, Rahnema M, Soltan Dallal MM. Evaluation of antimicrobial activity of Lactobacillus acidophilus and investigated the anti-pathogenic properties of Lactobacillus strains against anaerobic pathogens of the digestive system and demonstrated their positive impact against these pathogens (15).

In our study also, lactic acid bacteria showed good inhibitory effects on pathogenic bacteria. The created inhibition zones against pathogenic bacteria in the disk method were larger than the well method in all cases. Moreover, the acidic supernatants showed greater inhibition ability compared to the neutral supernatant.

\section{CONCLUSION}

The results were favorable and all species were able to inhibit the pathogenic bacteria with variable inhibition amounts based on the type of performed procedure (disk and plate) and the supernatant (acidic and neutral).

\section{ACKNOWLEDGMENTS}

I'd like to express my gratitude to Ms. Elham Alikhani and Sheida Akbari for their cooperation in conducting this study.

\section{CONFLICT OF INTEREST}

Therer are no conflicts of interest.

Lactobacillus routerion the several pathogenic bacteria of the enterobacteriaceae family. Journal of Microbial Biotechnology. 2011; 3(9): 29-34.

10. Boris S, Jimenez-Diaz R, Caso JL, Barbes C. Partial characterization of a bacteriocin produced by Lactobacillus delbrueckii subsp. lactis U0004. an intestinal isolate with probiotic potential. J Appl Microbiol. 2001; 91(2): 32-33.

11. Coconnier MH, Liévin V, Hemery E, Servin AL. Antagonistic activity against Helicobacter infection in vitro and in vivo by the human Lactobacillus acidophilus strain LB. Appl Environ Microbiol. 1998; 64(11): 4573-4580.

12. Ogunbanwo ST, Sanni AI, Onilude AA. Characterization of bacteriocin produced by Lactobacillus plantarum F1 and Lactobacillus brevis OG1. African Journal of Biotechnology. 2003; 2(8): 219-227.

13. Ouwehand AC, Kirjavainen PV, Shortt C, Salminen S. Probiotic: Mechanisms and established effects. International Dairy Journal. 1999; 9(1): 43-52.

14. Savadogo A, Cheik A. Antimicrobial activities of lactic acid bacteria strains isolated from Burkina faso fermented milk. Pakistan Journal of nutrition. 2004; 3(3): 174-179.

15. Strus M, Pakosz K, Gosciniak H. Antagonistic activity of Lactobacillus bacteria strains against anaerobic gastrointestinal tract pathogens (Helicobacter pylori, Campilobacter coli, Campilobacter jejuni, Clostridium difficile). Medycyna Doswiadczalna i Mikrobiobiologia. 2001; 53(2): 133-142. 